\title{
Disinfection by Ozone Microbubbles Can Cause Morphological Change of Fusarium oxysporum f. sp. melonis Spores
}

\author{
Masahiko Tamaki iㅁ ${ }^{1 *}$, Fumiyuki Kobayashi ${ }^{2}$, Hiromi Ikeura ${ }^{3}$, and Michio Sato ${ }^{1}$ \\ ${ }^{1}$ School of Agriculture, Meiji University, Kawasaki, Kanagawa 214-8571, Japan \\ ${ }^{2}$ Faculty of Applied Life Science, Nippon Veterinary and Life Science University, Musashino, Tokyo 180-8602, Japan \\ ${ }^{3}$ Faculty of Life and Environmental Science, Shimane University, Matsue, Shimane 690-8504, Japan
}

(Received on November 12, 2017; Revised on March 21, 2018; Accepted on April 23, 2018)

To investigate the difference in the disinfectant efficiency of ozone microbubbles $\left(\mathrm{O}_{3} \mathrm{MB}\right)$ and ozone millibubbles $\left(\mathrm{O}_{3} \mathrm{MMB}\right)$, the morphological change of the treated Fusarium oxysporum f. sp. melonis spores was observed with scanning and transmission electron microscopies (SEM and TEM). The disinfectant efficiency of $\mathrm{O}_{3} \mathrm{MB}$ on $F$. oxysporum $f$. sp. melonis spores was greater than that of $\mathrm{O}_{3} \mathrm{MMB}$. On observation with SEM, it was revealed that morphological change of $F$. oxysporum $\mathrm{f}$. sp. melonis spores was caused by $\mathrm{O}_{3} \mathrm{MB}$ and $\mathrm{O}_{3} \mathrm{MMB}$, and damage to the spore surfaces by $\mathrm{O}_{3} \mathrm{MB}$ occurred sooner than that by $\mathrm{O}_{3}$ MMB. On observation with TEM, it was furthermore confirmed that $F$. oxysporum f. sp. melonis spores treated with $\mathrm{O}_{3} \mathrm{MB}$ induced wavy deformation of cell membrane and the intracellular change different from that with $\mathrm{O}_{3} \mathrm{MMB}$. Therefore, the greater disinfection efficiency of $\mathrm{O}_{3} \mathrm{MB}$ was suggested to be caused due to the function of the MB in addition to the oxidative power of $\mathrm{O}_{3}$.

Keywords : disinfection, Fusarium oxysporum f. sp. melonis spores, ozone microbubbles

Handling Associate Editor : Jeon, Junhyun

\footnotetext{
*Corresponding author.

Phone) +81-44-980-5276, FAX) +81-44-980-5276

E-mail)mtamaki@meiji.ac.jp

ORCID

http://orcid.org/0000-0001-8316-725X

(c) This is an Open Access article distributed under the terms of the Creative Commons Attribution Non-Commercial License (http:// creativecommons.org/licenses/by-nc/4.0) which permits unrestricted noncommercial use, distribution, and reproduction in any medium, provided the original work is properly cited.
}

Articles can be freely viewed online at www.ppjonline.org.
Hydroponic culture is a plant cultivation technique in which plants are grown in a nutrient solution without soil. It has the potential for high crop productivity in a small area. However, if plant pathogens enter the solution, they can spread rapidly throughout the hydroponic culture facility and cause catastrophic damage. For this reason, disinfection of the solution is essential, although direct administration of pesticides into the solution has been prohibited at law (Ministry of Agriculture, Forestry and Fisheries, 2010). Therefore, it is desired to establish safe and effective alternative disinfection methods, and the various disinfection treatments have been investigated, including UV light, heat, the titanium dioxide photocatalytic reaction, and ozone $\left(\mathrm{O}_{3}\right)$ (Bando et al., 2008; Dannehl et al., 2016; Ehret et al., 2001; Igura et al., 2004; Koohakan et al., 2003; Ohtani et al., 2000; Runia, 1995). However, these treatments still are not put into any practical use in terms of the efficiency, treatment time, and running cost. Particularly, $\mathrm{O}_{3}$ gas is effective disinfectant due to its strong oxidation power, although it is difficult to use in hydroponic cultures because of its extremely low solubility in water $(0.105 \mathrm{~g}$ $100 \mathrm{ml}^{-1}\left(0^{\circ} \mathrm{C}\right)$ ).

Recently, tiny bubbles less than $50 \mu \mathrm{m}$ in diameter, called microbubble (MB), have been studied and used in many fields. They rise more slowly in water than millibubbles (MMB), which have diameters in the $\mathrm{mm}$ to $\mathrm{cm}$ range (Takahashi et al., 2003; Takahashi, 2005), and possess additional properties such as the interface charge, long stagnation, slow buoyancy, the shrinkage and the generation of free radicals by their collapsing other than dissolving power ( $\mathrm{Li}$ and Tsuge, 2006; Li et al., 2009; Zheng et al., 2015). Previously, we focused on long retention time in water and the dissolving power of $\mathrm{MB}$ in addition to the strong oxidative power of $\mathrm{O}_{3}$, and found that $\mathrm{O}_{3} \mathrm{MB}$ were more effective than $\mathrm{O}_{3} \mathrm{MMB}$ for the disinfection of $\mathrm{Fu}$ sarium oxysporum $\mathrm{f}$. sp. melonis spore and Pectobacterium 
carotovorum subsp. carotovorum in nutrient solution for hydroponic culture (Kobayashi et al., 2011a, 2011b, 2011c, 2012). Furthermore, effective disinfection by $\mathrm{O}_{3} \mathrm{MB}$ has been reported by other researchers (Chuajedton et al., 2015; Inatsu et al., 2011), although it is still not clear about the exact mechanism of disinfection by $\mathrm{O}_{3} \mathrm{MB}$. In this study, the morphological change of $F$. oxysporum $\mathrm{f}$. sp. melonis spores by $\mathrm{O}_{3} \mathrm{MB}$ and $\mathrm{O}_{3} \mathrm{MMB}$ was therefore observed by using scanning and transmission electron microscopies (SEM and TEM), and the difference was discussed.

F. oxysporum f. sp. melonis NBRC6385 suspension (approximately $1.0 \times 10^{7}$ spores $\mathrm{ml}^{-1}$ ) was prepared in a manner similar to a previous report (Kobayashi et al., 2011a). For each experiment, 151 of tap water were collected in a plastic cylindrical container $(28 \mathrm{~cm}$ dia. $\times 48 \mathrm{~cm}$ height) and kept for $24 \mathrm{~h}$ at room temperature to remove chlorine. Water quality test paper (Nissan aquacheck 3; Nissan Chemical Industries, Ltd., Tokyo, Japan) was used to confirm that no residual chlorine remained. $\mathrm{O}_{3}$ was generated by using an $\mathrm{O}_{3}$ generator (ED-OG-A10, Ecodesign Co. Ltd., Saitama, Japan) at a flow rate of $2.51 \mathrm{~min}^{-1}$. $\mathrm{O}_{3} \mathrm{MB}$ and $\mathrm{O}_{3} \mathrm{MMB}$ were generated by using a decompression type MB generator (20NEDO4S, Shigen-Kaihatsu Co., Ltd., Kanagawa, Japan) and a commercial air pump, respectively. The concentration of dissolved $\mathrm{O}_{3}$ in both $\mathrm{O}_{3} \mathrm{MB}$ and $\mathrm{O}_{3} \mathrm{MMB}$ waters was set to $1.5 \mathrm{ppm}$ at $15^{\circ} \mathrm{C}$. The $\mathrm{pH}$ of $\mathrm{O}_{3} \mathrm{MB}$ and $\mathrm{O}_{3} \mathrm{MMB}$ waters was the same at 6.8 and was not changed before and after $\mathrm{O}_{3} \mathrm{MB}$ and $\mathrm{O}_{3} \mathrm{MMB}$ generation. F. oxysporum f. sp. melonis spores were added to $100 \mathrm{ml}$ of the $\mathrm{O}_{3} \mathrm{MB}$ and $\mathrm{O}_{3} \mathrm{MMB}$ waters with final concentrations of $1.0 \times 10^{3}-1.0 \times 10^{4} \mathrm{cfu} \mathrm{ml}^{-1}$. Aliquots of the treated waters were collected after $0,15,30,45,60$ and 120 s. Aliquots of $0.1 \mathrm{ml}$ of the collected waters were plated on potato dextrose agar (Difco, Becton Dickinson, Flanklin Lakes, NJ, USA) plates, and the plates were incubated at $30^{\circ} \mathrm{C}$ for $48 \mathrm{~h}$. After incubation, the numbers of surviving spores were measured by counting the colonies formed on the plates. The detection limit was $10 \mathrm{cfu} \mathrm{ml}^{-1}$. Each experiment was performed in duplicate.

F. oxysporum f. sp. melonis spores were collected from $5 \mathrm{ml}$ of the suspension by filtration with a cartridge filter (Anotop 10, GE Healthcare UK Ltd., Buckinghamshire, UK). The sample on the cartridge filter was pre-fixed with $2.5 \%$ glutalaldehyde solution diluted with a phosphate buffer solution (PBS, pH 7.0). A filter ejected by decomposing the cartridge filter was washed with $\mathrm{PBS}(\mathrm{pH} 7.0)$, post-fixed with $2 \% \mathrm{OsO}_{4}$ solution for $1 \mathrm{~h}$, and then serially dehydrated for $20 \mathrm{~min}$ each in $50 \%, 70 \%, 80 \%, 90 \%$, $95 \%, 99.5 \%$ and dehydrated ethanol. SEM observations were performed as follows: The dehydrated sample was immersed in a mixture of t-butyl alcohol and dehydrated ethanol (1:1) for about $10 \mathrm{~min}$, transferred to $100 \%$ t-butyl alcohol, freeze-dried with a freeze drier (ES-2030, Hitachi High Technologies Co., Tokyo, Japan), and $\mathrm{OsO}_{4}$-coated with a $\mathrm{OsO}_{4}$ coater (HPC-1SW, Vacuum device Inc., Mito, Japan) (the thickness of the coating was adjusted to $3 \mathrm{~nm}$ ). Then the sample was observed with an SEM (JSM-6700F, JEOL Ltd., Akishima, Japan) operated at $3.0 \mathrm{kV}$. Nine $F$. oxysporum f. sp. melonis spores in the SEM photographs were selected at random and the widths was measured with a scale. Significant differences were evaluated by the ANOVA and Fisher's LSD using the Ekuseru-Toukei 2012 for Window statistical software (Social Survey Research Information Co., Ltd., Tokyo, Japan) $(P<0.05)$. TEM observations were performed as follows: The dehydrated samples were serially immersed for $2 \mathrm{~h}$ each in 1:1, 2:1, and 3:1 mixtures of Quetol-651 (Cosmo Bio Co., Ltd., Tokyo, Japan) and ethylene glycol diglycidyl ether, and then embedded in $100 \%$ Quetol- 651 at $60^{\circ} \mathrm{C}$. Ultra-thin sections (thickness 70-100 nm) were made from the embedded samples with an ultramicrotome (ULTRA CUT UCT, Leica Microsystems, Wetzlar, Germany). The ultra-thin sections were doubly electron-strained using $4 \%$ uranyl acetate for $12 \mathrm{~min}$ and lead nitrate for $5 \mathrm{~min}$, and then observed with a TEM (JEM-2010, JEOL Ltd.) operated at $140 \mathrm{kV}$.

The survival rates of $F$. oxysporum f. sp. melonis spores in water treated with $\mathrm{O}_{3} \mathrm{MB}$ and $\mathrm{O}_{3} \mathrm{MMB}$ are shown in Fig. 1. The disinfectant efficiency of $\mathrm{O}_{3} \mathrm{MB}$ on $F$. oxysporum f. sp. melonis spores was greater than that of $\mathrm{O}_{3} \mathrm{MMB}$, because the numbers of surviving spores after treatment with $\mathrm{O}_{3} \mathrm{MB}$ and $\mathrm{O}_{3} \mathrm{MMB}$ reached the detection limit at 45 $\mathrm{s}$ and $60 \mathrm{~s}$, respectively. The result agreed with our previous study (Kobayashi et al., 2011a). Amount of hydroxyl

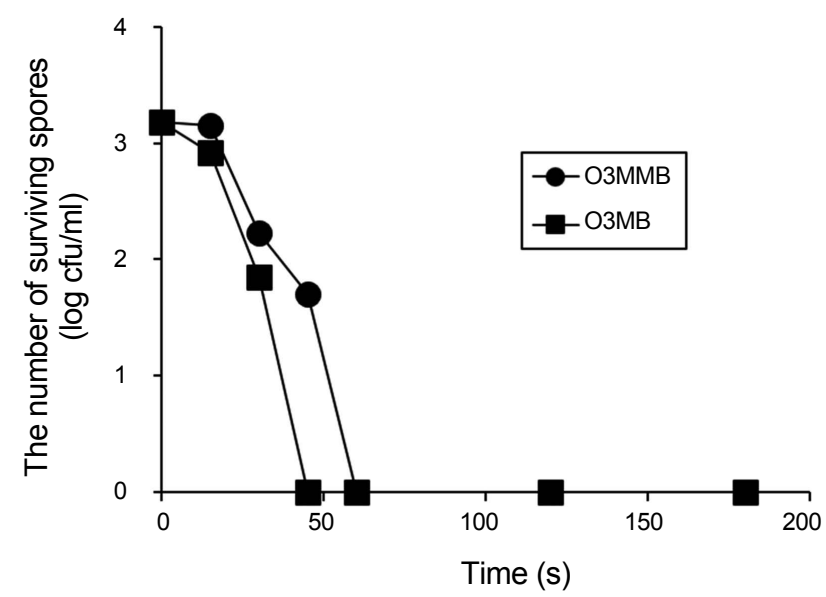

Fig. 1. Disinfection of $F$. oxysporum $\mathrm{f}$. sp. melonis spores by $\mathrm{O}_{3} \mathrm{MB}$ and $\mathrm{O}_{3} \mathrm{MMB}$. The data presented was the mean of duplicate. 


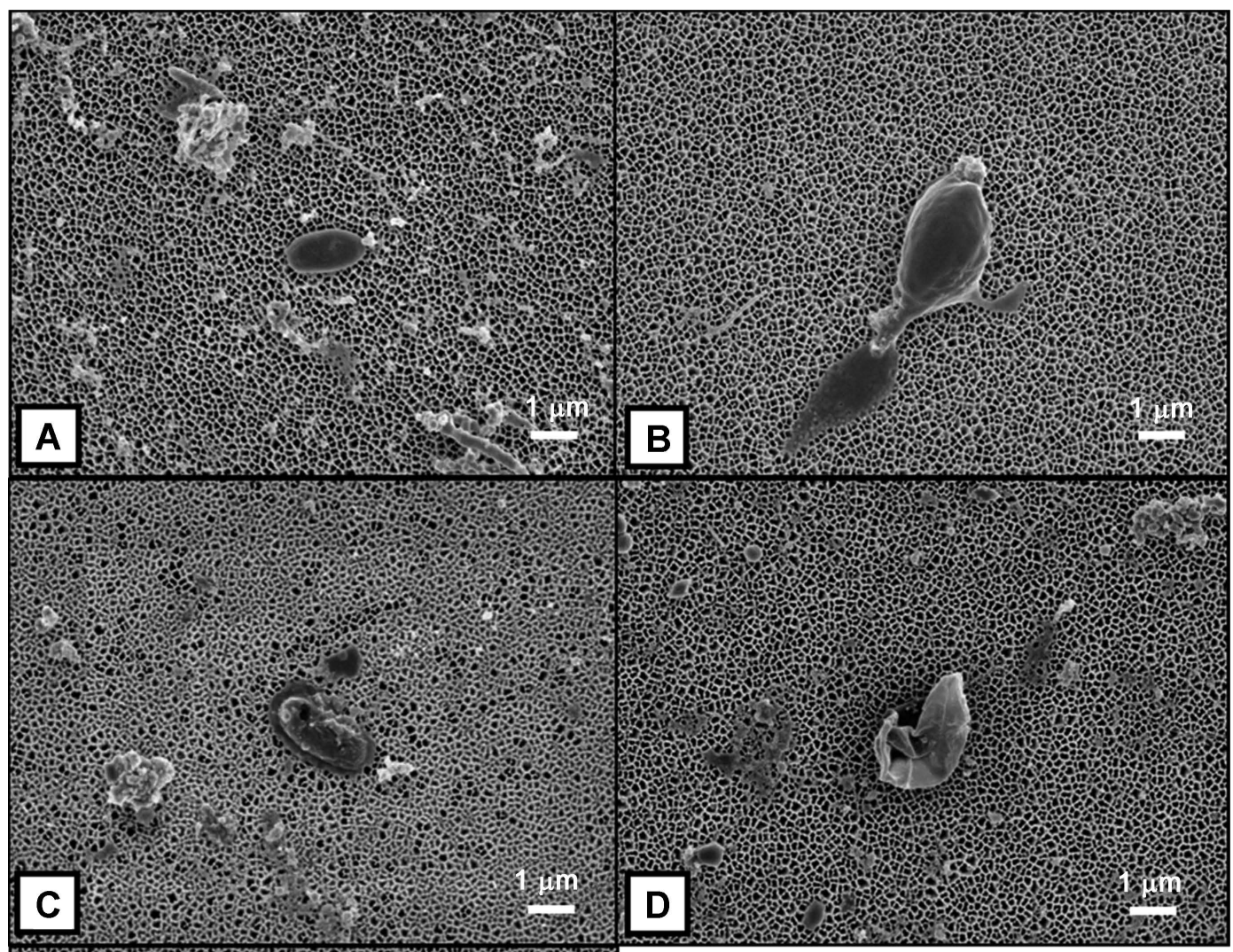

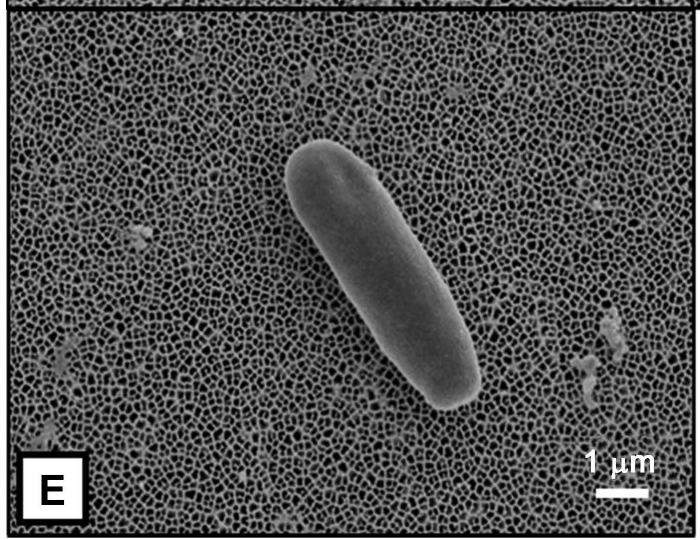

radicals generated from $\mathrm{O}_{3}$ is not enough to have a disinfectant effect (Cho et al., 2003). However, $\mathrm{O}_{3} \mathrm{MB}$ may generate more hydroxyl radicals than $\mathrm{O}_{3} \mathrm{MMB}$, because the oxidation-reduction potential and iodine liberation is higher with $\mathrm{O}_{3} \mathrm{MB}$ than with $\mathrm{O}_{3} \mathrm{MMB}$ (Chuajedton et al., 2015). Furthermore, the use of MB enhances the formation of hydroxyl radicals due to more rapid $\mathrm{O}_{3}$ decomposition (Tsuge et al., 2009), and the hydroxyl radicals generated from $\mathrm{O}_{3} \mathrm{MB}$ accelerate the oxidative power (Chu et al., 2008). The high oxidative power of $\mathrm{O}_{3} \mathrm{MB}$ contributes to the oxidative power of $\mathrm{O}_{3}$, the reactivity of the hydroxyl radicals, the substantivity, $\zeta$ surface potential, mass-transfer coefficient, and use efficiency (Zheng et al., 2015). Therefore,
Fig. 2. SEM images of $F$. oxysporum f. sp. melonis spores. (A) After treatment with $\mathrm{O}_{3} \mathrm{MMB}$ for $30 \mathrm{~s}$, (B) After treatment with $\mathrm{O}_{3} \mathrm{MMB}$ for $60 \mathrm{~s}$, (C) After treatment with $\mathrm{O}_{3} \mathrm{MB}$ for $30 \mathrm{~s}$, (D) After treatment with $\mathrm{O}_{3} \mathrm{MB}$ for $60 \mathrm{~s}$, (E) Non-treated.

the greater disinfectant efficiency of $\mathrm{O}_{3} \mathrm{MB}$ than $\mathrm{O}_{3} \mathrm{MMB}$ is likely be due to these synergistic effects.

The SEM images of $F$. oxysporum f. sp. melonis spores treated with $\mathrm{O}_{3} \mathrm{MB}$ and $\mathrm{O}_{3} \mathrm{MMB}$ are shown in Fig. 2. The spores treated with $\mathrm{O}_{3} \mathrm{MMB}$ for $30 \mathrm{~s}$ showed no obvious surface injury, although spores treated with $\mathrm{O}_{3} \mathrm{MMB}$ for $180 \mathrm{~s}$ were deformed. On the other hand, spores treated with $\mathrm{O}_{3} \mathrm{MB}$ showed obvious surface injury after $30 \mathrm{~s}$ and the spores were completely destroyed after $180 \mathrm{~s}$. The widths of $F$. oxysporum f. sp. melonis spores treated with $\mathrm{O}_{3} \mathrm{MMB}$ for $30 \mathrm{~s}$ were lower than those of non-treated spores, and then the spores swelled after $180 \mathrm{~s}$ (Fig. 3). However, the widths of spores treated with $\mathrm{O}_{3} \mathrm{MB}$ for 30 


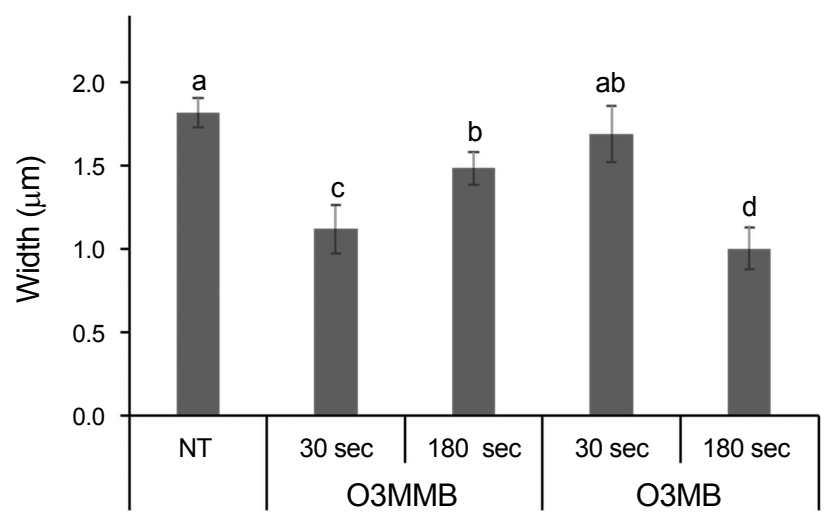

Fig. 3. The widths of F. oxysporum $\mathrm{f}$. sp. melonis spores in SEM images. NT: Non-treated. The results indicate the means with standard deviation of 9 spores. $\mathrm{s}$ were the same as those of non-treated spores and diminished in size by $180 \mathrm{~s}$. Furthermore, the TEM images indicated the appearance of liquid foam in the mid-regions of the $F$. oxysporum f. sp. melonis spores treated with $\mathrm{O}_{3} \mathrm{MMB}$ for $180 \mathrm{~s}$ (Fig. 4). Then, the spores had swelled by $\mathrm{O}_{3} \mathrm{MMB}$ for $180 \mathrm{~s}$, as water entered the cells through the damaged cell wall. Cho et al. (2010) reported that disinfection of bacterial cells by $\mathrm{O}_{3}$ was due to injury of the cell wall. Zhang et al. (2011) showed that disinfection of Pseudomonas aeruginosa by $\mathrm{O}_{3}$ was due to increase in cell membrane permeability and coagulation of the intracellular substrate. Thanomsub et al. (2002) concluded that disinfection by $\mathrm{O}_{3}$ was caused due to the destruction of the cell wall and leakage of the intracellular substrate, followed by

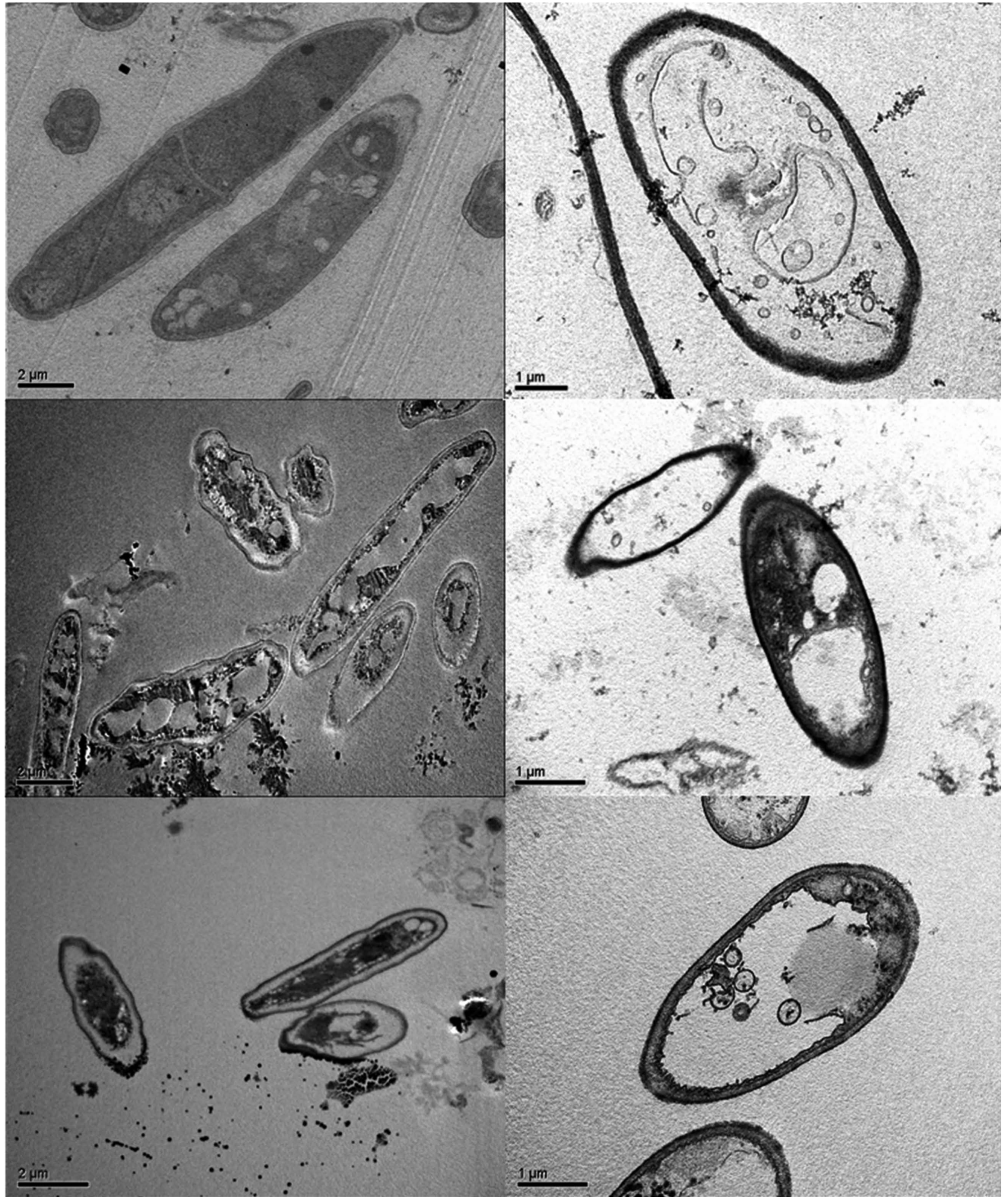

Fig. 4. TEM images of $F$. oxysporum f. sp. melonis spores. Top: Non-treated, Middle: After treatment with $\mathrm{O}_{3} \mathrm{MMB}$ for $180 \mathrm{~s}$, Bottom: After treatment with $\mathrm{O}_{3} \mathrm{MB}$ for $180 \mathrm{~s}$. 
cell lysis. Therefore, it is possible that the $F$. oxysporum $\mathrm{f}$. sp. melonis spores treated with $\mathrm{O}_{3} \mathrm{MMB}$ for $30 \mathrm{~s}$ initially shrank due to leakage of the intracellular substrate through the damaged cell wall. On the other hand, the TEM images of the $F$. oxysporum f. sp. melonis spores treated with $\mathrm{O}_{3} \mathrm{MB}$ for $180 \mathrm{~s}$ showed the wavelike deformation of cell membrane and appeared to have a space between the cell membrane and/or wall and the cytoplasm. Diao et al. (2004) confirmed that hydroxyl radicals generated by the Fenton reaction induced the injury of $E$. coli cell membranes greater than $\mathrm{O}_{3}$ by the observation with SEM. Therefore, it appears that hydroxyl radicals generated from the $\mathrm{O}_{3} \mathrm{MB}$ induces the wavy injury of cell membrane of $F$. oxysporum f. sp. melonis spores. Furthermore, it was considered that coagulation of the substrate within the spores and leakage of the substrate through the damaged cell membrane were induced by the higher amounts of hydroxyl radicals generated from the tiny $\mathrm{O}_{3} \mathrm{MB}$ penetrated into the spores. The result may lead to cell death due to the leakage and/or coagulation of the intracellular substrate, followed by the lysis of the spore.

These results show that disinfection efficiency of $\mathrm{O}_{3} \mathrm{MB}$ on $F$. oxysporum $\mathrm{f}$. sp. melonis spores is higher than that of $\mathrm{O}_{3}$ MMB and may be due to the action of MB in combination with the high oxidative power of the $\mathrm{O}_{3}$. Therefore, it is considered that disinfection of $F$. oxysporum $\mathrm{f}$. sp. melonis spores by $\mathrm{O}_{3} \mathrm{MB}$ causes the leakage and/or coagulation of intracellular components associated with damage to the cell membrane and/or cell wall, and subsequently leads to lysis of the spore.

\section{References}

Bando, K., Kawano, M., Kuroda, Y., Kusakari, S., Yamasaki, M., Maeda, T. and Kourai, H. 2008. Effect of silver-supported photocatalytic sterilization, yield, quality, and nutrient element concentrations in the tomato grown under rockwool culture. Hortic. Res. (Japan) 7:309-315 (in Japanese).

Cho, M., Chung, H. and Yoon, J. 2003. Disinfection of water containing natural organic matter by using ozone-initiated radical reactions. Appl. Environ. Microbiol. 69:2284-2291.

Cho, M., Kim, J., Kim, J. Y., Yoon, J. and Kim, J. H. 2010. Mechanisms of Escherichia coli inactivation by several disinfectants. Water Res. 44:3410-3418.

Chu, L. B., Xing, X. H., Yu, A. F., Sun, X. L. and Jurcik, B. 2008. Enhanced treatment of practical textile wastewater by microbubble ozonation. Process Saf. Environ. Prot. 86:389-393.

Chuajedton, A., Nuanaon, N., Uthaibutra, J. and Whangchai, K. 2015. Ozone microbubbles disinfection technique to inactivate penicillium digitatum in suspension. Acta Hortic. 1088:355-358.
Dannehl, D., Schuch, I., Gao, Y., Cordiner, S. and Schmidt, U. 2016. Effects of hypochlorite as a disinfectant for hydroponic systems on accumulations of chlorate and phytochemical compounds in tomatoes. Eur. Food Res. Technol. 242:345353.

Diao, H. F., Li, X. Y., Gu, J. D., Shi, H. C. and Xie, Z. M. 2004. Electron microscopic investigation of the bactericidal action of electrochemical disinfection in comparison with chlorination, ozonation and Fentone reaction. Process Biochem. 39:1421-1426.

Ehret, D. L., Alsanius, B., Wohanka, W., Menzies, J. G. and Utkhede, R. 2001. Disinfestation of recirculating nutrient solutions in greenhouse horticulture. Agronomie 21:323-339.

Igura, N., Fujii, M., Shimoda, M. and Hayakawa, I. 2004. Inactivation efficiency of ozonated water for Fusarium oxysporum conidia under hydroponic greenhouse conditions. Ozone Sci. Eng. 26:517-521.

Inatsu, Y., Kitagawa, T., Nakamura, N., Kawasaki, S., Nei, D., Bari, L. and Kawamoto, S. 2011. Effectiveness of stable ozone microbubble water on reducing bacteria on the surface of selected leafy vegetables. Food Sci. Technol. Res. 17:479485.

Kobayashi, F., Ikeura, H., Ohsato, H., Goto, T. and Tamaki, M. 2011a. Disinfection using ozone microbubbles to inactivate Fusarium oxysporum f. sp. melonis and Pectobacterium carotovorum subsp. carotovorum. Crop Prot. 30:1514-1518.

Kobayashi, F., Ikeura, H., Ohsato, S. and Tamaki, M. 2011 b. Microbicidal effect of microbubbles with ozone, oxygen, and carbon dioxide against Fusarium oxysporum f. sp. melonis and Pectobacterium carotovorum subsp. carotovorum. Journal of the Japanese Society of Agricultural Technology Management 18:123-128.

Kobayashi, F., Ikeura, H., Ohsato, S. and Tamaki, M. 2011c. Microbicidal effect of ozone microbubbles generated by different methods on Fusarium oxysporum f. sp. melonis and Pectobacterium carotovorum subsp. carotovorum. Journal of the Japanese Society of Agricultural Technology Management 18:129-134.

Kobayashi, F., Ikeura, H., Ohsato, S., Goto, T. and Tamaki, M. 2012. Ozone microbubbles as a disinfection in nutrient solution, and their effects on the composition of fertilizer and the growth of cultivated plants. Biol. Eng. Trans. 5:137-146.

Koohakan, P., Ikeda, H., Kusakari, S., Masuda, T., Mano, K. and Masuda, R. 2003. Effects of $\mathrm{TiO}_{2}$ photocatalytic sterilizing system on the suppression of tomato root rot disease in the nutrient solution. Hortic. Res. (Japan) 2:215-219 (in Japanese).

Li, P. and Tsuge, H. 2006. Ozone transfer in a new gas-induced contactor with microbubbles. J. Chem. Eng. Jpn 39:12131220.

Li, P., Takahashi, M. and Chiba, K. 2009. Degradation of phenol by the collapse of microbubbles. Chemosphere 75:13711375.

Ministry of Agriculture, Forestry and Fisheries. 2010. Agricul- 
tural Chemicals Regulation Act. URL http://www.maff.go.jp/ $\mathrm{j} /$ nouyaku/n_kaisei/zenbun.html/.

Ohtani, T., Kaneko, A., Fukuda, N., Hagiwara, S. and Sase, S. 2000. Development of a membrane disinfection system for closed hydroponics in a greenhouse. J. Agric. Eng. Res. 77:227-232.

Runia, W. T. 1995. A review of possibilities for disinfection of recirculation water from soilless cultures. Acta Hortic. 382:221229.

Takahashi, M. 2005. $\zeta$ potential of microbubbles in aqueous solutions: electrical properties of the gas-water interface. J. Phys. Chem. B 109:21858-21864.

Takahashi, M., Kawamura, T., Yamamoto, Y., Ohnari, H., Himuro, S. and Shakutsui, H. 2003. Effect of shrinking microbubble on gas hydrate formation. J. Phys. Chem. B 107:21712173.
Thanomsub, B., Anupunpisit, V., Chanphetch, S., Watcharachaipong, T., Poonkhum, R. and Srisukonth, C. 2002. Effects of ozone treatment on cell growth and ultrastructural changes in bacteria. J. Gen. Appl. Microbiol. 48:193-199.

Tsuge, H., Li, P., Shimatani, N., Shimamura, Y., Nakata, H. and Ohira, M. 2009. Fundamental study on disinfection effect of microbubbles. Kagaku Kogaku Ronbunshu 35:548-552 (in Japanese).

Zhang, Y. Q., Wu, Q. P., Zhang, J. M. and Yang, X. H. 2011. Effect of ozone on membrane permeability and ultrastructure in Pseudomonas aeruginosa. J. Appl. Microbiol. 111:1006-1015.

Zheng, T., Wang, Q., Zhang, T., Shi, Z., Tian, Y., Shi, S., Smale, N. and Wang, J. 2015. Microbubble enhanced ozonation process for advanced treatment of wastewater produced in acrylic fiber manufacturing industry. J. Hazard. Mater. 287:412-420. 